\title{
Effect of Buctril Super (Bromoxynil) Herbicide on Soil Microbial Biomass and Bacterial Population
}

\author{
Zafar Abbas $^{1 *}$, Muhammad Akmal ${ }^{1}$, Khalid Saifullah Khan ${ }^{1}$ and Fayyaz-ul-Hassan ${ }^{2}$ \\ ${ }^{1}$ Department of Soil Science \& SWC; PMAS-Arid Agriculture University Rawalpindi - Pakistan. ${ }^{2}$ Department of \\ Agronomy; PMAS-Arid Agriculture University Rawalpindi - Pakistan
}

\begin{abstract}
The present study aimed to evaluate the effect of bromoxynil herbicide on soil microorganisms, with the hypothesis that this herbicide caused suppression in microbial activity and biomass by exerting toxic effect on them. Nine sites of Punjab province (Pakistan) those had been exposed to bromoxynil herbicide for about last ten years designated as soil 'A' were surveyed in 2011 and samples were collected and analyzed for Microbial Biomass Carbon (MBC), Biomass Nitrogen $(M B N)$, Biomass Phosphorus (MBP) and bacterial population. Simultaneously, soil samples from the same areas those were not exposed to herbicide designated as soil ' $B$ ' were taken. At all the sites $M B C, M B N$ and $M B P$ ranged from 131 to 457, 1.22 to 13.1 and 0.59 to $3.70 \mu \mathrm{g} \mathrm{g}^{-1}$ in the contaminated soils (Soil A), which was 187 to $573,1.70$ to 14.4 and 0.72 to $4.12 \mu \mathrm{g} \mathrm{g}^{-1}$ in the soils without contamination (soil B). Bacterial population ranged from 0.67 to $1.84 \times 10^{8}$ and 0.87 to $2.37 \times 10^{8} \mathrm{cfu} \mathrm{g}^{-1}$ soil in the soils $A$ and B, respectively. Bromoxynil residues ranged from 0.09 to $0.24 \mathrm{mg} \mathrm{kg}^{-1} \mathrm{at}$ all the sites in soil A. But no residues were detected in the soil B. Due to lethal effect of bromoxynil residues on the above parameters, considerable decline in these parameters was observed in the contaminated soils. Results depicted that the herbicide had left toxic effects on soil microbial parameters, thus confirmed that continuous use of this herbicide affected the quality of soil and sustainable crop production.
\end{abstract}

Key words: biomass, buctril super, bacteria, effect, population

\section{INTRODUCTION}

Soil microbial biomass defined by (Jenkinson and Ladd 1981) is "the living part of soil organic matter, excluding the plant roots and soil animals larger than about $5 \times 10^{3} \mu \mathrm{m}^{3}$. . It comprises numerous species of bacteria, fungi along with larger soil microorganisms including protozoa, algae and yeast. Assessment of the microbial biomass carbon and nitrogen of the soil provide a mean of estimating the response of microbes to the changes in soil management operations (Mc Grath et al. 1995; Dai et al. 2004). Singh and Ghoshal (2010) reported that for sustainable agro- ecosystem, soil microbial biomass and biological productivity are most essential. Soil microbial biomass comprise only $2-6 \%$ of total organic matter of soil but being highly mobile constituent of the organic matter, it plays major role in nutrient cycling (Anderson and Domsch 1980). Soil microbial biomass contain substantial amount of carbon, nitrogen, phosphorus and calcium (Anderson and Domsch 1980) and plays important role by mediating the nutrient cycling and flow of energy (Bardegu et al. 1997). It acts as soil ecological marker because of its active involvement in nutrient release and due to major role in soil structure formation (Smith and Paul

*Author for correspondence: zafar_75@yahoo.com 
1990). Microbial biomass mediated organic matter transformation has proved that it acted as a source of nutrient elements in the soils having poor nutrient (Kang et al. 2012). Many studies have reported the negative as well as positive effects of the herbicides on soil microbial biomass and soil microorganisms. Microorganisms operate as a sign of soil quality due to their key role in different soil functions (Scholter et al. 2003). In enzymes activity, the microbial biomass play vital role and acts as best indicator of different changes taking place in the soil (Gonzales et al. 2007). But applied herbicides are injurious for soil microorganisms. About 20\% decrease in microbial biomass carbon was observed by Vischetti et al. (2002) by applying 50\% dose of imazamox. Injurious effect of rimsulfuron and imazethapyr herbicide when applied at field rates and ten times of field rates on soil microbes and biochemical properties of soil was reported by Perucci et al. (2000). The toxic effects of bromoxynil herbicide on soil microbes has been reported in different studies (El-Ghamry et al. 2000; Pampulha and Oliveira, 2006; Maria et al. 2008). Allievi and Gigliotti (2001) noticed decrease in amino acid assimilation ability of bacteria leading to their death consequently decline in microbial biomass due to sulfonyl urea herbicide. Bromoxynil herbicide resulted decrease in the population of bacteria that were involved in nitrification (Ratnayak and Audus 1987). Inhibition in the activity of ammonium oxidizing bacteria by bromoxynil has also been reported by Pampulha and Oliveira (2006).

In Pakistan buctril super (bromoxynil) herbicide is being used most frequently for the control of the weeds, which inhibits the photosynthesis and ultimately leads to the death of weeds. Bacteria involved in nitrification process showed highest sensitivity to bromoxynil herbicide. So their activity declined in the presence of bromoxynil herbicide in soil (Edward et al. 1993). Increase in the population of actinomycetes and bacteria by applying the recommended dose of bromoxynil, while decrease in their population at higher concentration of this herbicide has been observed by Omer and Abdul Sater (2000). Keeping in view the above, this work aimed to quantify the effect of buctril super (bromoxynil) herbicide on MBC, MBN and MBP and to evaluate the effect of buctril super on soil bacteria in southern Punjab, Pakistan.

\section{MATERIALS AND METHODS}

\section{Experimental Details}

Nine different sites of the district Dera Ghazi Khan and Multan were surveyed and soil samples were collected from those sites (Table 1) during March, 2011 where buctril super herbicide was being used for weed control for the last ten years (designated as soil 'A'). Simultaneously, soil samples from the same areas those were not exposed to herbicide (designated as soil ' $\mathrm{B}$ ' as a control) were analyzed for basic physico-chemical properties as well as for soil microbial biomass carbon, microbial biomass nitrogen, microbial biomass phosphorus and bacterial population.

Table 1 - GPS Locations of experimental Sites

\begin{tabular}{|c|c|c|c|}
\hline Sites & Particulars & $\mathbf{N}$ & $\mathbf{E}$ \\
\hline $\mathrm{S}_{1}$ & $\begin{array}{l}\text { D.G.Khan } \\
\text { (Shadun Lund) }\end{array}$ & $30^{\circ}\left(28.09^{\prime}\right)$ & $70^{\circ}\left(43.38^{\prime}\right)$ \\
\hline $\mathrm{S}_{2}$ & $\begin{array}{l}\text { D.G.Khan } \\
\text { (Shah Saddar Din) }\end{array}$ & $30^{\circ}\left(16.33^{\prime}\right)$ & $70^{\circ}\left(43.45^{\prime}\right.$ \\
\hline $\mathrm{S}_{3}$ & $\begin{array}{l}\text { Kot Addu } \\
\text { (Daira Din Pannah) }\end{array}$ & $30^{\circ}\left(33.11^{\prime}\right)$ & $70^{\circ}\left(56.35^{\prime}\right.$ \\
\hline $\mathrm{S}_{4}$ & Taunsa (Dona) & $30^{\circ}\left(42.13^{\prime}\right)$ & $70^{\circ}\left(56.35^{\prime}\right.$ \\
\hline $\mathrm{S}_{5}$ & $\begin{array}{l}\text { Taunsa } \\
\text { (Tibbi Qaisrani) }\end{array}$ & $30^{\circ}\left(42.14^{\prime}\right)$ & $70^{\circ}(38.21$ \\
\hline $\mathrm{S}_{6}$ & Taunsa (Sokar) & $30^{\circ}\left(42.14^{\prime}\right)$ & $70^{\circ}\left(38.24^{\prime}\right)$ \\
\hline $\mathrm{S}_{7}$ & Taunsa (Vehova) & $30^{\circ}\left(42.19^{\prime}\right)$ & $70^{\circ}\left(38.26^{\prime}\right.$ \\
\hline $\mathrm{S}_{8}$ & $\begin{array}{l}\text { Multan } \\
\text { (Qadirpur Raan) }\end{array}$ & $30^{\circ}\left(17.25^{\prime}\right)$ & $71^{\circ}(39.56$ \\
\hline$S_{9}$ & Multan (Sher Shah) & $30^{\circ}\left(12.26^{\prime}\right)$ & $71^{\circ}\left(27.22^{\prime}\right)$ \\
\hline
\end{tabular}

\section{Microbial Biomass Carbon, Nitrogen and Phosphorus Analysis}

The determination of microbial biomass carbon (MBC) was done by fumigation and extraction method (Vance et al. 1987). Two samples (10 g each) were extracted with $50 \mathrm{~mL} 0.5 \mathrm{M} \mathrm{K}_{2} \mathrm{SO}_{4}$ and filtered. Two other samples were fumigated with alcohol-free chloroform at $25^{\circ} \mathrm{C}$ for $24 \mathrm{~h}$. These samples were also extracted with $0.5 \mathrm{M} \mathrm{K}_{2} \mathrm{SO}_{4}$ and filtered. $\mathrm{MBC}$ was calculated as $\mathrm{MBC}=$ (Extracted $\mathrm{C}$ from fumigated soil - Extracted C from unfumigated soil) $\times 2.64$ and carbon from the extracts was estimated by the method described by Nelson and Sommer (1982). Total N was estimated by Kjeldahl method illustrated by Bremner (1982). The MBN was calculated as $\mathrm{MBN}=($ Extracted $\mathrm{N}$ from fumigated soil Extracted $\mathrm{N}$ from unfumigated soil) $\mathrm{x} 1.46$ (Brookes et al. 1985). The MBP was estimated by extraction of soil samples with $0.5 \mathrm{M} \mathrm{NaHCO}_{3} \mathrm{pH}$ 8.5. The extracted $\mathrm{P}$ was determined by using ammonium molybdate and ascorbic acid. $\mathrm{KH}_{2} \mathrm{PO}_{4}$ 
was used for phosphorus standards preparation and reading was recorded through the spectrophotometer at $880 \mathrm{~nm}$. The MBP was calculated as $\mathrm{MBP}=($ Extracted $\mathrm{P}$ from fumigated soil - Extracted $\mathrm{P}$ from unfumigated soil) $\mathrm{x} 2.5$ (Brookes et al. 1982).

\section{Bacterial population count}

The colony forming units of bacteria were counted by using the dilution plate technique. Fresh soil $(1.0 \mathrm{~g})$ was taken and serial dilutions were made. Tryptone Soya Agar (TSA) modified by cyclohexamide $\left(100 \mathrm{mg} \mathrm{L}^{-1}\right)$ was used. The plates were inoculated with soil suspension $(0.1 \mathrm{~mL})$ and stored at $28^{\circ} \mathrm{C}$ for about 3-5 days, (William and Wellington 1982).

\section{Bromoxynil Residue Analysis}

Bromoxynil residues in the soil were determined by using the Model SCL-10A VP. Soil (10g) was taken in centrifuge tube along with acetonitrile (20 $\mathrm{ml}$ ) followed by $5.0 \mathrm{~mL}$ distilled water containing $0.1 \%$ formic acid (v/v). Acetonitrile supernatant $(10 \mathrm{ml})$ was concentrated to less than $1.0 \mathrm{~mL}$ on evaporator at $50^{\circ} \mathrm{C}$. The solution was transferred to HPLC sample vial. Mobile phase was methanol: water: formic acid $=60: 40: 0.1$ (on volume basis) with $800 \mu \mathrm{Lmin}^{-1}$ flow rate and the wave-length of detection was $254 \mathrm{~nm}$. The volume of injection was $20 \mu \mathrm{L}$. Retention time for bromoxynil was 10.3 min. (Chen et al. 2011).

\section{Statistical Analysis}

Descriptive statistics was applied and data represented as mean \pm standard deviation of three replications.

\section{RESULTS}

The physico-chemical properties of soil ' $A$ ' and soil ' $\mathrm{B}$ ' are given in Table 2 . At all the sites, the microbial biomass carbon ranged from131 to $457 \mu \mathrm{g} \mathrm{g}^{-1}$ with an average of $221 \pm 96 \mu \mathrm{g} \mathrm{g}^{-1}$ in the soil A, while in the soil B, it ranged from 187 to $573 \mu \mathrm{g} \mathrm{g}^{-1}$ with an average of $279 \pm 119 \mu \mathrm{g} \mathrm{g}^{-1}$ (Table 3). The highest biomass carbon of 457 and $573 \mu \mathrm{g} \mathrm{g}^{-1}$ was recorded at Sher Shah in the soil ' $A$ ' and 'B', respectively, which showed $20 \%$ decline in the former soil. The lowest biomass carbon of 131 and $187 \mu \mathrm{g} \mathrm{g}^{-1}$ was recorded at Kot Adu with $30.3 \%$ decline in the ' $A$ '. In the exposed soils, the microbial biomass nitrogen ranged 1.22 to $13.1 \mu \mathrm{g} \mathrm{g}^{-1}$ with an average of $6.87 \pm 4.54 \mu \mathrm{g} \mathrm{g}^{-1}$, but in unexposed soils, it ranged 1.70 to $14.4 \mu \mathrm{g} \mathrm{g}^{-1}$ with an average of $7.71 \pm 4.84 \mu \mathrm{g} \mathrm{g}^{-1}$.

Table 2 - Physico-chemical properties of soil A and soil B.

\begin{tabular}{|c|c|c|c|c|c|c|c|c|c|c|}
\hline \multirow[b]{2}{*}{ Sites } & \multicolumn{5}{|c|}{ Soil A (Herbicide applied soil) } & \multicolumn{5}{|c|}{ Soil B (Soil without herbicide application) } \\
\hline & pH & $\begin{array}{c}\text { Soil } \\
\text { Texture }\end{array}$ & $\begin{array}{c}\text { TOC } \\
(\%)\end{array}$ & $\begin{array}{c}\mathrm{EC} \\
\left(\mathrm{dSm}^{-1}\right)\end{array}$ & $\begin{array}{c}\text { Bromoxynil } \\
\text { Residues } \\
\left(\mathrm{mg} \mathrm{kg}^{-1}\right)\end{array}$ & pH & $\begin{array}{c}\text { Soil } \\
\text { Texture }\end{array}$ & $\begin{array}{c}\text { TOC } \\
(\%)\end{array}$ & $\begin{array}{c}\mathrm{EC} \\
\left(\mathrm{dSm}^{-1}\right)\end{array}$ & $\begin{array}{c}\text { Bromoxynil } \\
\text { Residues } \\
\left(\mathrm{mg} \mathrm{kg}^{-1}\right)\end{array}$ \\
\hline $\mathbf{S}_{1}$ & 8.0 & Clay & 0.4002 & 0.37 & 0.09 & 8.1 & Clay & 0.5112 & 0.38 & -- \\
\hline $\mathbf{S}_{2}$ & 8.0 & Clay & 0.2001 & 0.38 & 0.21 & 8.0 & Clay & 0.2804 & 0.36 & -- \\
\hline $\mathbf{S}_{3}$ & 8.2 & Sandy clay & 0.1901 & 0.39 & 0.18 & 8.1 & Sandy clay & 0.3014 & 0.39 & -- \\
\hline $\mathbf{S}_{4}$ & 7.9 & Clay & 0.3001 & 4.20 & 0.24 & 7.8 & Clay & 0.3994 & 4.21 & -- \\
\hline $\mathbf{S}_{5}$ & 7.7 & Clay & 0.2201 & 0.41 & 0.09 & 7.7 & Clay & 0.2608 & 0.40 & -- \\
\hline$S_{6}$ & 7.4 & Loam & 0.2601 & 0.35 & 0.14 & 7.2 & Loam & 0.2987 & 0.35 & -- \\
\hline $\mathbf{S}_{7}$ & 8.2 & Clay Loam & 0.2801 & 0.43 & 0.19 & 8.0 & Clay Loam & 0.3102 & 0.43 & -- \\
\hline $\mathbf{S}_{8}$ & 8.1 & Clay Loam & 0.2401 & 0.53 & 0.15 & 8.0 & Clay Loam & 0.2705 & 0.52 & -- \\
\hline$S_{9}$ & 8.0 & $\begin{array}{l}\text { Sandy } \\
\text { clay loam }\end{array}$ & 0.8404 & 0.51 & 0.13 & 7.9 & $\begin{array}{l}\text { Sandy } \\
\text { clay loam }\end{array}$ & 0.8801 & 0.51 & -- \\
\hline
\end{tabular}

Table 3 - Maximum, minimum and average ( \pm standard deviation) values of microbial biomass carbon, nitrogen, phosphorus and bacterial population of soil A and soil B.

\begin{tabular}{|c|c|c|c|c|c|c|c|c|c|c|c|c|}
\hline \multirow[t]{2}{*}{ Soils } & \multicolumn{3}{|c|}{$\operatorname{MBC}\left(\mu g g^{-1}\right)$} & \multicolumn{3}{|c|}{$\mathrm{MBN}\left(\mu \mathrm{g} \mathrm{g}^{-1}\right)$} & \multicolumn{3}{|c|}{ MBP $\left(\mu \mathrm{g} \mathrm{g}^{-1}\right)$} & \multicolumn{3}{|c|}{ Bacterial population $\left(\# \times 10^{8}\right)$} \\
\hline & Min & Max & Average & Min & $\operatorname{Max}$ & Average & Min & Max & Average & Min & Max & Average \\
\hline Soil A & 131 & 457 & $221 \pm 96$ & 1.22 & 13.1 & $6.87 \pm 4.54$ & 0.59 & 3.70 & $2.01 \pm 0.94$ & 0.67 & 1.84 & $1.23 \pm 0.37$ \\
\hline Soil B & 187 & 573 & $279 \pm 119$ & 1.70 & 14.4 & $7.71 \pm 4.84$ & 0.72 & 4.12 & $2.59 \pm 1.06$ & 0.87 & 2.37 & $1.69 \pm 0.56$ \\
\hline
\end{tabular}

At site-8 (Qadirpur Raan), the MBN was $13.1 \mu \mathrm{g}$ $\mathrm{g}^{-1}$ in the soil ' $\mathrm{A}$ ' and $14.4 \mu \mathrm{g} \mathrm{g}^{-1}$ in the soil ' $\mathrm{B}$ ', which showed $9 \%$ decline in the soil A. The minimum MBN of $1.22 \mu \mathrm{g} \mathrm{g}^{-1}$ was at Tibbi 
Qaisrani in the soil ' $\mathrm{A}$ ' and $1.70 \mu \mathrm{g} \mathrm{g}^{-1}$ in the soil 'B', which showed $28.3 \%$ reduction in the MBN in soil A. Microbial biomass phosphorus ranged 0.59 to $3.7 \mu \mathrm{g} \mathrm{g}^{-1}$ with an average of $2.01 \pm 0.94 \mu \mathrm{g}$ $\mathrm{g}^{-1}$ in the contaminated soils, while in uncontaminated soils, it ranged 0.72 to $4.12 \mu \mathrm{g} \mathrm{g}^{-1}$ with an average of $2.01 \pm 0.94 \mu \mathrm{g} \mathrm{g} \mathrm{g}^{-1}$. The maximum MBP value of $3.7 \mu \mathrm{g} \mathrm{g}^{-1}$ at Sher Shah was in soil ' $\mathrm{A}$ ' and $4.12 \mu \mathrm{g} \mathrm{g}^{-1}$ in soil ' $\mathrm{B}$ ' from the same site, which showed $10.2 \%$ decline in the MBP in soil A. Site-5 (Tibbi Qaisrani) showed minimum MBP value of $0.59 \mu \mathrm{g} \mathrm{g}^{-1}$ in the soil ' $\mathrm{A}$ ' while in the soil 'B', it was $0.72 \mu \mathrm{g} \mathrm{g}^{-1}$ indicating $18 \%$ decrease in the MBP in soil 'A'. Bacterial population ranged from $0.67 \times 10^{8}$ to $1.84 \times 10^{8} \mathrm{cfu}$ $\mathrm{g}^{-1}$ soil with an average of $1.23 \times 10^{8} \pm 0.37$ in the contaminated soils, while in the uncontaminated soils, it ranged from $0.98 \times 10^{8}$ to $2.37 \times 10^{8} \mathrm{cfu} \mathrm{g}^{-1}$ with an average of $1.6910^{8} \pm 0.56$. The highest bacterial population recorded was $1.84 \times 10^{8} \mathrm{cfu} \mathrm{g}^{-1}$ at Dona in the ' $\mathrm{A}$ ' and $2.37 \times 10^{8} \mathrm{cfu} \mathrm{g}^{-1}$ soil from the same site in soil ' $\mathrm{B}$ ', which showed $22.36 \%$ decrease in the soil ' $A$ '. The lowest bacterial population of $0.67 \times 10^{8} \mathrm{cfu}^{-1}$ soil at Qadirpur Raan was in soil ' $\mathrm{A}$ ' and $0.87 \times 10^{8} \mathrm{cfu} \mathrm{g}^{-1}$ soil in soil 'B', which indicated $23 \%$ decrease in the soil 'A'.

\section{DISCUSSION}

In the present study, significant reduction in biomass carbon was recorded at all the experimental sites where soil was exposed to herbicide as compared to soil not exposed to herbicide. The level of soil microbial biomass carbon was lowest in the soil with the highest levels of bromoxynil herbicide residues. The results indicated that herbicide had affected soil microorganisms, causing decline in their population, ultimately leading to decrease in biomass carbon. Highest reduction in the biomass carbon $(35.17 \%)$ at $S_{2}$ in soil ' $A$ ' as compared to soil 'B' (Table 4) was due to high $\mathrm{pH}$ at $\mathrm{S}_{2}$ because some herbicides were more persistent because of their restricted hydrolysis at high $\mathrm{pH}$ resulting more time of exposure to the microbes, leading to their death, which resulted decrease in biomass carbon. Franzen and Zolinger (1997) reported enhanced persistence of triazine herbicide in the soil having high $\mathrm{pH}$. Similar decline in biomass carbon was reported by Omar (1994) with the application of bromoxynil herbicide.

Table 4 - Microbial biomass carbon, nitrogen, phosphorus and bacterial population in Soil A and Soil B.

\begin{tabular}{|c|c|c|c|c|c|c|c|c|}
\hline \multirow[b]{2}{*}{ Sites } & \multicolumn{4}{|c|}{ Soil A (Herbicide applied soil) } & \multicolumn{4}{|c|}{ Soil B (Soil without herbicide application) } \\
\hline & $\begin{array}{c}\text { MBC } \\
\left(\mu \mathrm{g} \mathrm{g}^{-1}\right)\end{array}$ & $\begin{array}{c}\text { MBN } \\
\left(\mu \mathrm{g} \mathrm{g}^{-1}\right)\end{array}$ & $\begin{array}{c}\text { MBP } \\
\left(\mu \mathrm{g} \mathrm{g}^{-1}\right)\end{array}$ & $\begin{array}{c}\text { Bacterial cfu/g } \\
\text { soil }\left(\# X 10^{8}\right)\end{array}$ & $\begin{array}{c}\mathrm{MBC} \\
\left(\mu \mathrm{g} \mathrm{g} \mathrm{g}^{-1}\right)\end{array}$ & $\begin{array}{c}\text { MBN } \\
\left(\mu \mathrm{g} \mathrm{g}^{-1}\right)\end{array}$ & $\begin{array}{c}\text { MBP } \\
\left(\mu \mathrm{g} \mathrm{g}^{-1}\right)\end{array}$ & $\begin{array}{c}\text { Bacterial cfu/g } \\
\text { soil }\left(\# X 10^{8}\right)\end{array}$ \\
\hline S1 & $261 \pm 13.1$ & $4.14 \pm 0.42$ & $1.64 \pm 0.24$ & $1.42 \pm 0.04$ & $335 \pm 18.9$ & $4.87 \pm 0.42$ & $2.13 \pm 0.19$ & $1.98 \pm 0.03$ \\
\hline $\mathrm{S} 2$ & $163 \pm 19.6$ & $5.35 \pm 1.12$ & $3.04 \pm 0.46$ & $1.13 \pm 0.04$ & $253 \pm 7.54$ & $6.08 \pm 0.84$ & $3.91 \pm 0.17$ & $1.95 \pm 0.15$ \\
\hline S3 & $131 \pm 6.53$ & $7.79 \pm 0.42$ & \pm 0.07 & 05 & $187 \pm 10.0$ & $27 \pm 0.42$ & $87 \pm 0$ & 0.08 \\
\hline S4 & $196 \pm 13.1$ & $1.70 \pm 0.42$ & $1.42 \pm 0.07$ & $4 \pm 0.17$ & $246 \pm 16.4$ & $2.43 \pm 0.42$ & $2.10 \pm 0.2$ & $2.37 \pm 0.08$ \\
\hline S5 & $163 \pm 13.1$ & $1.22 \pm 0.42$ & $0.59 \pm 0.00$ & $1.42 \pm 0.06$ & $189 \pm 6.53$ & $1.70 \pm 0.42$ & $0.72 \pm 0.03$ & $1.98 \pm 0.01$ \\
\hline S6 & $196 \pm 13.1$ & $4.62 \pm 1.12$ & $1.83 \pm 0.11$ & $1.02 \pm 0.05$ & $224 \pm 13.6$ & $5.11 \pm 0.73$ & $2.36 \pm 0.21$ & $1.27 \pm 0.10$ \\
\hline S7 & $196 \pm 11.3$ & $11.70 \pm 0.73$ & $2.25 \pm 0.07$ & $0.76 \pm 0.05$ & $237 \pm 15.1$ & $13.1 \pm 0.73$ & $3.14 \pm 0.11$ & $0.98 \pm 0.18$ \\
\hline $\mathrm{S}_{8}$ & $228 \pm 11.3$ & $13.1 \pm 1.46$ & $2.33 \pm 0.24$ & $0.67 \pm 0.06$ & $264 \pm 10.0$ & $14.4 \pm 0.42$ & $2.97 \pm 0.24$ & $0.87 \pm 0.10$ \\
\hline $\mathrm{S}_{9}$ & $457 \pm 17.3$ & $12.2 \pm 1.12$ & $3.71 \pm 0.06$ & $1.34 \pm 0.06$ & $573 \pm 7.54$ & $13.4 \pm 2.35$ & $4.12 \pm 0.23$ & $1.51 \pm 0.08$ \\
\hline
\end{tabular}

The inhibition in the population of bacteria and fungi was reported by Nowak et al. (1999) due to use of post-emergence herbicides, leading to decrease in the microbial biomass carbon. Tenfold decrease in the total population of soil microorganisms has been reported by Khalid et al. (2001) by post-emergence herbicides tralkoxydim and fenoxyprop-p-ethyly.

Decrease in bacteria, fungi and actinomycetes population has been reported by Sebiomo et al. (2011) due to atrazine, primeextra, paraquot and glyphosate herbicides application. They also reported considerable decrease in soil organic matter due to paraquot and glyphosate herbicides treatments. About 25 and $64.7 \%$ decrease in the biomass carbon contents has been reported by Vischetti et al. (2002) due to imazamox and benfluralin herbicides, respectively. This reduction in the biomass carbon might be because of decrease in organic matter in the soil due to the mortality of soil microbes by the herbicide residues. Considerable changes in organic matter content in the soil were noticed by Ayansina and Oso (2006) by the application of atrazine. 
Reduction in the microbial biomass nitrogen was similar to biomass carbon at all the experimental sites. The highest decline (21.52\%) in the MBN was recorded at $\mathrm{S}_{4}$ in the soil ' $\mathrm{A}$ ' as compared to soil 'B'. High organic matter contents at $S_{4}$ had extended herbicide persistence in the soil and its exposure to soil microbes ultimately caused their death due to which MBN declined. Yaron et al. (1985) observed that the soil containing high organic matter exhibited elevated microbial activity. However, these soils had the capacity to adsorb the applied herbicide more tightly, therefore, decreasing its concentration in soil solution, and thus protecting the herbicide from biodegradation; ultimately prolonging its persistence in the soil. Decrease in the MBN could also be due to the harmful effect of bromoxynil residues $\left(0.24 \mathrm{mg} \mathrm{kg}^{-1}\right)$ on soil microorganisms in the soil ' $A$ '. This decrease would be because of high sensitivity of nitrogen fixing bacteria to the herbicide. Bacteria involved in nitrogen fixation (Azotobacter) were highly sensitive to the herbicide (Nada et al. 2002) and showed inhibition in herbicide treated soil. The suppression of heterotrophic bacteria due to the application of metsulfuron methyl herbicide was reported by $\mathrm{He}$ et al. (2006). Decline in biomass nitrogen could be because of the toxicity of herbicide residues to rhizobia due to which nodule formation and nitrogen fixation were affected badly and resulted decline in biomass nitrogen. The inhibition of rhizobia and nodule formation due to herbicide application was also observed by Singh and Wright (2002). This decrease in MBN might be due to high electrical conductivity $\left(4.21 \mathrm{dSm}^{-1}\right)$. High salt concentration in the soil solution exerted osmotic stress on microbial population, so their population decreased; consequently, the MBN decreased. The present results were in agreement with the results of Yuan et al. (2007). They reported strong negative correlation between microbial biomass nitrogen and electrical conductivity of the soil. Similar decrease in the MBN was reported by Shah et al. (2011) due to the osmotic stress induced by elevated salinity.

At all the sites significant decrease in microbial biomass phosphorus was noticed in the soil ' $\mathrm{A}$ ' as compared to the soil ' $\mathrm{B}$ '. The maximum reduction $(28.87 \%)$ in the MBP at $\mathrm{S}_{3}$ and $(32.38 \%)$ at $\mathrm{S}_{4}$ was observed. This decrease in MBP could be because of reduction in the total microbial population due to the toxic effect of herbicide residues on soil microorganisms. The toxic effect of herbicides (rimsulfuron and imazethapyr) on soil microorganisms and various biochemical reactions taking place in the soil have been reported in earlier studies (Perucci et al. 2000), and as a consequence, decrease in total soil microbial biomass (MBC, MBN and MBP). Poor root growth of the weeds due to suppression of weeds by the herbicide might also be the reason for decline in the organic matter, so low organic matter contents resulted decrease in the MBP.

The MBP decline might be because of the detrimental effect of herbicide residues on the activity of phosphorus solubilizing microbes. This could result in alteration in microbial membrane permeability and released phosphatase enzymes. Significant decrease in phosphate solubilizing bacteria (Enterobacter asburiae) was reported by Ahmad and Khan (2010) due to quizalafop-pethyl, clodinifop, metribuzin, glyphosate herbicides. They found that quizalafop-p-ethyl herbicide alone when applied @ 40,80 and $120 \mu \mathrm{g} / \mathrm{L}$ exerted 72,91 and $94 \%$ poisonous effect, respectively on phosphate solubilizing activity of $E$. asburiae over the control.

Bacterial population showed considerable decline at all the sites in soil ' $A$ '. The highest drop in bacterial population ( $42 \%)$ at $S_{2}$ in the soil ' $A$ ' as compared to soil ' $\mathrm{B}$ ' was attributed towards high clay contents at $\mathrm{S}_{2}$. Elevated clay contents lengthened the persistence of herbicide in the soil and prolonged time of exposure of the herbicide to soil bacteria, resulting decline in their population. Cupples et al. (2005) also observed prolonged persistence of herbicide due to high clay contents in the soil. This drop in bacterial population might be because of rapid mortality of bacteria due to herbicide. Busse et al. (2001) reported toxic effect of glyphosate on the bacteria and fungi. Decrease in bacterial population in soil ' $A$ ' could be due to the injurious effect of herbicide on rhizobial growth and development, thus hampering nodule formation and nitrogen fixation. The present results were in agreement with the results of Singh and Wright (2002), who reported harmful effect of herbicide on rhizobia. The decrease could be attributed due to the reduction in organic matter contents due to reduction in the roots of weeds. Same inhibition in enzymes activity due to buctril super herbicide application because of reduction of stimulatory effect of weeds roots was observed by Niemi et al. (2009). 


\section{CONCLUSIONS}

Soil microbial biomass and microbial population are integral part of soil environment. Balanced agro-ecosystem is dependent on microbial population and microbial biomass. This study indicated that buctril super (bromoxynil) herbicide had left severe detrimental effect on soil microbial biomass and bacterial population in those soils containing high organic matter, elevated clay contents and high $\mathrm{pH}$ because of its prolonged persistence in such soils. Therefore, much care is required while applying this herbicide to such soils in order to protect the soil microbial diversity and to protect the soil health on sustainable basis.

\section{REFERENCES}

Allievi L, Gigliotti C. Response of the bacteria and fungi of two soils to the sulfonylurea herbicide cinosulfuron. J Environ Sci Health. 2001; 36: 161175.

Anderson JPE, Domsch KH. Quantities of plant nutrients in the microbial biomass of selected soils. Soil Sci. 1980; 130: 211-216.

Ayansina AD, Oso BA. Effect of two commonly used herbicides on soil microflora at two different concentrations. African J Biotech. 2006; 5: 129- 132.

Brookes P, Kragt JF, Powlson DS, Jenkinson DS. Chloroform fumigation and the release of soil nitrogen: the effects of fumigation time and temperature. Soil Biol Biochem. 1985; 17(6): 831835 .

Brookes PC, Powlson DS. Jenkinson DS. Measurement of microbial biomass phosphorus in soil. Soil Biol Biochem. 1982; 14(4): 319-329.

Busse MD, Ratcliff AW, Shestak CJ. Glyphosate toxicity and the effects of long- term vegetation control on soil microbial communities. Soil Biol Biochem. 2001; 1777-1789.

Chen X, Li W. Bromoxynil residues and dissipation rates in maize crops and soil. Ecotoxicol Environ Saf. 2011.

Cupples AM, Sanford RA, Sims GK. Dehalogenation of the herbicides bromoxynil (3, 5-dibromo-4hydroxybenzonitrile) and ioxynil (3,5-diiodino-4hydroxybenzonitrile) by desulfitobacterium chlororespirans. Appl Environ Microbiol. 2005; 71(7): 3741-3746.

Dai J, Beequer T, Rouiller JH, Reversat G, Lavelle P. Influence of heavy metals on $\mathrm{C}$ and $\mathrm{N}$ mineralization and microbial biomass in $\mathrm{Zn}, \mathrm{Pb}, \mathrm{Cu}$ and $\mathrm{Cd}$ contaminated soil. Appl Soil Ecol. 2004; 25: 99-109.
El-Ghamry AM, Chang-yong H, Jian-ming X. Influence of chlorsulfuran herbicide on size of microbial biomass in soil. J Environ Sci. 2000; 12(2): 138-143.

He Y, Shen H, Fang DS, He CR, Zhu YM. Effects of metsulfuron- methyl on the microbial population and enzyme activities in wheat rhizosphere soil. J Environ Sci Health B. 2006; 41(3): 269-84.

Jenkinson DS, Ladd JN. Microbial biomass in soil: measurements and turnover. Soil Biochem. 1981.

Kang SM, Khan AL, Hamayun M. Acinetobacter calcoaceticus ameliorated plant growth and influenced gibberellins and functional biochemicals. Pak J Bot. 2012; 44(1): 365-372.

McGrath SP, Chaudhry AM, Giller KE. Long-term effects of metals in sewage sludge on soils, microorganisms and plants. J Ind Microbiol. 1995; 14:94-104.

Niemi RM, Heiskanen I, Ahtiainen JH, Rahkonen A, Mäntykoski K, Welling L, Laitinen P, Ruuttunen P. Microbial toxicity and impacts on soil enzyme activities of pesticides used in potato cultivation. Appl Soil Ecol. 2009; 41: 293-304.

Omar SA, AbdelSater MA. Microbial population and enzyme activities in soil treated with pesticides. Water, Air and soil Pollution. 2001; 127: 49-63.

Perucci P, Dumontet S, Bufo SA, Mazzatura A, Casucci C. Effects of organic amendment and herbicides treatment on soil microbial biomass. Biol Fertil Soils. 2000; 32: 17-23.

Pampulha ME, Oliveira A. Impact of an herbicide combination of bromoxynil and prosulfuron on soil microorganisms. Current Microbiol. 2006; 53: 238243.

Ratnayake M, Audus LJ. Studies on the effects of herbicides on soil nitrification. II. Pest Biochem Physiol.1978; 8: 170-185.

Schloter M, Dilly O, Munch JC. Indicators for evaluating soil quality. Agric Ecosyst Environ. 2003; 98: 255-262.

Sebiomo A, Ogundero VW, Bankole SA. Effect of four herbicides on microbial population, soil organic matter and dehydrogenase activity. African J Biotech. 2011; 10 (5): 770-778.

Singh P, Ghoshal N. Variation in total biological productivity and soil microbial biomass in rainfed agro ecosystems: Impact of application of herbicide. Agric Ecosyst Environ. 2012; 137: 241-250.

Smith J. Paul E. The significance of soil microbial biomass estimations. Soil Biochem. 1990; 6: 357-396.

Williams ST. Wellington EMH. Methods of soil analysis II, Chemical and microbiological properties. American Soc Agron Inc. 1982; 969-387.

Yaron B. Gerstl Z. Spencer WF. Behavior of herbicides in irrigated soils. Adv Soil Sci. 1985; 121-211. 